\section{Money, Career, and Life}

Between 2006 and 20I4, the proportion of employers doubled, who considered international experience important for recruitment and paid higher salaries to employees with international experience.

Erasmus students are half as likely as nonmobile students to be long-term unemployed; five years after graduation, their unemployment rate is substantially lower. Ten years after graduation, Erasmus alumni are considerably more likely to hold managerial positions. They are also far more inclined to take a job abroad than nonmobile students.

In addition, Erasmus influences the entrepreneurial attitude: one third of the students on Erasmus work placements were offered a job by their host company, and nearly Io percent started their own businesses; approximately ten times the usual rate among graduates.

Another objective of Erasmus is to contribute to creating a European identity among students and graduates. Indeed 80 percent of Erasmus students feel a strong attachment to Europe. This sense of belonging seems to be particularly reinforced by social or intimate ties with people from abroad: 33 percent of the Erasmus alumni stated that they had a life partner of a different nationality, while 27 percent had met their current life partner during their stay abroad. Erasmus does change a person's life!

\section{Countering Campus}

\section{Extremism in Southeast Asia}

\section{Anthony Welch}

Anthony Welch is professor of education at the University of Sydney, Australia, and is a visiting professor at the National Higher Education Research Institute in Penang, Malaysia. E-mail: anthony.welch@sydney.edu.au.

- $x$ tremism has long been part of higher education. The -1 suppression of Arabic and Jewish scholars in Spain during the I5th century, the Nazi persecution of Jewish and communist intellectuals, and the mass murder of scholars in Cambodia by the Khmer Rouge, are potent reminders of the tyranny of intolerance.

Now, Islamic extremism on campus is troubling higher education systems around the world, including many Muslim nations. The storied Al-Azhar University in Cairoa beacon of Islamic learning founded before Oxford or Cambridge - has just pledged to fight militant tendencies among its students. In acknowledging criticisms that it is fostering extremism, Al-Azhar president Abdel-Hai Azab, recently ordered the formation of academic committees charged with revising textbooks to purge them of radical jihadist ideas.

\section{Extremism in Southeast Asian Higher Education}

In Southeast Asia, too, rising campus radicalism has led to campaigns to curb its influence. But the present extremism did not spring from nowhere. Radical movements in the region are decades old and in some cases linked to the desire for regional autonomy, or to fighting for Islam in farflung places such as Afghanistan. Hundreds of Filipinos, Malaysians, and Indonesians-an unknown proportion of whom were young university students, volunteered as Mujahadeen warriors and returned radicalized.

\section{Islamic extremism on campus is trou- bling higher education systems around the world, including many Muslim na- tions.}

Indonesia in the I980 saw examples of radical Islamist movements, some associated with Hizb ut-Tahrir at universities such as Gadjah Mada in Jogjakarta and Bandung Institute of Technology. Hizb ut-Tahrir is currently banned in countries such as Germany, Russia, China, Saudi, Jordan, and Egypt but legal in the United Kingdom, Australia, and elsewhere, where repeated investigations have revealed no evidence of terrorist activities.

Most recently, a national deradicalization blueprint was developed, with a national terrorism prevention program that focused on the 13 most-affected provinces. It included strengthening the capacity of universities to resist terrorism. Yet, Institute for Policy Analysis of Conflict director Sidney Jones pointed out recently that training 575 trainers at Indonesian universities is of questionable value, since campuses have not been a particular target of violent extremists-partly because organizations such as Hizb utTahrir are active in keeping them out-and, since, as well, the details of the training module seem, at least so far, rather vague.

It is also not clear that the recent visit of radical clerics from Egypt to Indonesia, including their involvement in a conference at Universitas Indonesia, had much effect in tempering radicals. More successful have been visits to universities from members of groups-such as the Survivors Foundation (Yayasan Penyintas) and Association for Victims of Terrorism Bombings in Indonesia, who have shared their stories with students and staff. 
Islamic extremism in the Philippines can be partly traced back to effects of the Afghan war, during which hundreds of Muslim Filipinos, travelled to Pakistan and Afghanistan to join the mujaheddin. It is not clear how many may have been students. The militant Bangsamoro Islamic Freedom Fighters (BIFF) in the Philippines' south has openly pledged allegiance to Islamic State (sometimes called Da'esh), while Abu Sayyaf members were reported among slain jihadists in Syria. Nonetheless, the dean of the University of the Philippines' Institute of Islamic Studies expressed concern that media sensationalism provoked fear and potentially worsened the situation.

Like Indonesia, the Philippines also has used visits by prominent clerics, including from Egypt, recently at Mindanao State University. The visits have been attended by thousands of students and staff, with messages on the five pillars of faith, good governance, and peaceful coexistence with other communities of faith. In an eerie reminder, however, their visits paralleled a firefight between government military and the BIFF, which forced thousands of villagers to flee.

Thailand, too, has its problems with Salafist jihadist groups and with clumsy responses by the Thai military, although there is little evidence of extremist activity in universities in the southern-most border provinces of Yala, Narathiwat, and Pattani.

In Malaysia, an early example was Mohammed Fadly, a student at Universiti Teknologi Malaysia, who, after taking an oath of allegiance to Jemaah Islamiah, sought to fight for Islam in southern Thailand. Recently, increasing tensions between Malaysia's secular constitution and Islam as the state religion provoked a group of leading Malaysians, calling themselves the $\mathrm{G}_{4} \mathrm{O}$, to warn of increasing Islamization. In response to the radicalization of its youth, the Malaysian Islamic Development Department established a cross-agency committee to explain misconceptions surrounding jihad, notably including to Malaysia's universities. A Mahasiswa Islam Tolak Keganasan (Muslim Undergraduates Reject Violence) campaign hopes to use Muslim student leaders at universities to disseminate the real meaning of jihad. Support also has come from clerics in the form of a nationwide fatwa declaring that the call of jihad and martyrdom by Islamic State is un-Islamic. Malaysians who fought for Islamic State and died could not claim to be martyrs.

Malaysia has enhanced the scrutiny of international student applications, via the national agency Education Malaysia Global Services that manages all aspects of international student applications, including passport checks. As a result, rejection rates fell from 28 percent in 2012 , and 24 percent in 2012 , to only 3 percent in 2013 . Nonetheless, despite these efforts, a captured Hamas terrorist recently re- vealed that the organization is actively recruiting young Palestinians studying in Malaysia. In another case, a captured Hamas terrorist revealed that he had been sent to Malaysia, with 9 others, to train using hang gliders, in preparation for terrorist attacks against Israel. Some 40 Palestinian students were said to have been recruited in this manner. The recruitment and associated activities are allegedly centered on the International Islamic University of Malaysia, with one or two of its professors named as having been involved.

\section{Hearts and Minds?}

Such recruitment activities give cause for pause, regarding the success of regional hearts-and-minds campaigns, aimed at countering extremism. Of more than $\mathrm{I} 2,000$ foreigners who joined the fight in Syria last year, perhaps ro percent or more came from Southeast Asia and show the problem remains real. While the above shows that some terrorist recruits are international students (and some domestic), just how many were from the higher education sector remains unknown.

Ultimately, a solid foundation in what it means to be a good Muslim, as well as acceptance of Muslims within the wider society (in the case of Thailand and the Philippines), is needed to counter the attractions of groups such as Islamic State within the region's universities.

But more work remains to be done to counter the effects of extreme Islamist ideologies in the region's universities. If universities are sources of ideas, there is a need to harness this energy to research the phenomenon more fully, work with communities to promulgate a moderate Muslim message of peace and understanding, and promote a more inclusive form of democracy — which can undoubted weaken the appeal of extremism, to impressionable young university students.

\section{Greek Higher Education: Old Challenges and the Current Crisis}

\section{Dimitrios Dentsoras}

Dimitrios Dentsoras is assistant professor at the University of Manitoba, Canada. E-mail: Dimitrios.Dentsoras@umanitoba.ca. This article appeared in a different format in Stepping Into a New Era, edited by A. Glass (European Association for International Education, 2014 Conference Conversation Starter). 